\title{
Feeding habits of neon flying squid Ommastrephes bartramii in the transitional region of the central North Pacific
}

\author{
Hikaru Watanabe $^{1, *}$, Tsunemi Kubodera $^{2}$, Taro Ichii ${ }^{1}$, Shigeyuki Kawahara ${ }^{1}$ \\ ${ }^{1}$ National Research Institute of Far Seas Fisheries, 5-7-1 Orido Shimizu, Shizuoka 424-8633, Japan \\ ${ }^{2}$ National Science Museum, 3-23-1 Hyakunin-cho Shinjyuku, Tokyo 169-0073, Japan
}

\begin{abstract}
We examined the feeding habits of the neon flying squid Ommastrephes bartramii from late spring to mid-summer in relation to its northward migration in the transitional waters of the central North Pacific. The winter-spring cohort (ca. 15 to $25 \mathrm{~cm}$ in May and 20 to $35 \mathrm{~cm}$ in July) and the autumn cohort (ca. 30 to $45 \mathrm{~cm}$ in May and 35 to $50 \mathrm{~cm}$ in July) were identified by their dorsal mantle lengths. In May and July, the winter-spring cohort was distributed only in the transition zone (TZ) south of the subarctic boundary. This cohort preyed primarily on crustaceans such as euphausiids and amphipods in May, but in July, their primary prey shifted to the sternoptychid fish Maurolicus imperatorius. In May, the larger-sized autumn cohort was also distributed only in the TZ, but in July, these individuals migrated to the transitional domain (TD) north of the subarctic boundary. The main prey of the autumn cohort were micronektonic animals that dominated the TZ in May: the transitionalwater myctophid Symbolophorus californiensis, and 2 subtropical myctophids, Ceratoscopelus warmingi and Electrona risso. Secondary important prey items included the transitional-water squid Onychoteuthis borealijaponica and subarctic gonatid squids such as Gonatus berryi and Berryteuthis anonychus. In July, the main prey species in the TD were $S$. californiensis and O. borealijaponica, both of which also migrated from the TZ into the TD, crossing the subarctic boundary in summer. We estimated the feeding impact of the autumn squid cohort on myctophids in the TD during summer.
\end{abstract}

KEY WORDS: Neon flying squid · Feeding habits · Myctophid fishes · Seasonal migration . Transitional waters · Central North Pacific

\section{INTRODUCTION}

The neon flying squid Ommastrephes bartramii is an oceanic squid occurring worldwide in subtropical and temperate waters (Roper et al. 1984). It is one of the dominant large pelagic nekton in the North Pacific (Roper et al. 1984, Murata 1990, Murata \& Hayase 1993, Seki 1993a). The main habitat of this squid is the so-called transitional region of the North Pacific (Pearcy 1991), which consists of the transitional domain north of the subarctic boundary and the transition zone to the south (Favorite et al. 1976; Fig. 1). This species migrates south-north to feed between the subtropical region and the transitional domain, since the latter area is highly productive in summer (Taniguchi 1981, Murata 1990, Murata \& Hayase 1993).

Previous studies have indicated that in the transitional region of the North Pacific, neon flying squid feed mainly on micronektonic and small pelagic fishes such as myctophids, Japanese sardine, and saury, as well as on small pelagic cephalopods such as Berryteuthis anonychus (Shevstov 1972, Filippova 1974, Naito et al. 1977a, Tung 1981, Pearcy 1991, Seki 1993a,b, Arimoto \& Kawamura 1998). Neon flying squid are also important prey of larger fishes, such as swordfish and blue sharks, and marine mammals such as fur seals and sperm whales (Okutani et al. 1976, Okutani \& Satake 1978, Pearcy 1991, Seki 1993a, Mori et al. 2001). There- 
fore, Ommastrephes bartramii has been thought to play an important role in connecting animals of the tertiary trophic level with apex predators in oceanic food webs, although quantitative data on the feeding habits of this species are extremely limited.

From spring to summer, neon flying squid are found as a large-sized autumn cohort and a small-sized winter-spring cohort (Yatsu et al. 1998). We aimed to quantitatively examine the feeding habits of each cohort in the transitional waters of the central North Pacific from late spring to mid-summer and determine their feeding strategies in relation to their seasonal south-north migrations and diel vertical migrations. We also estimated the impact of feeding by the autumn cohort on the biomass of myctophids in the transitional domain during the summer.

(a) May

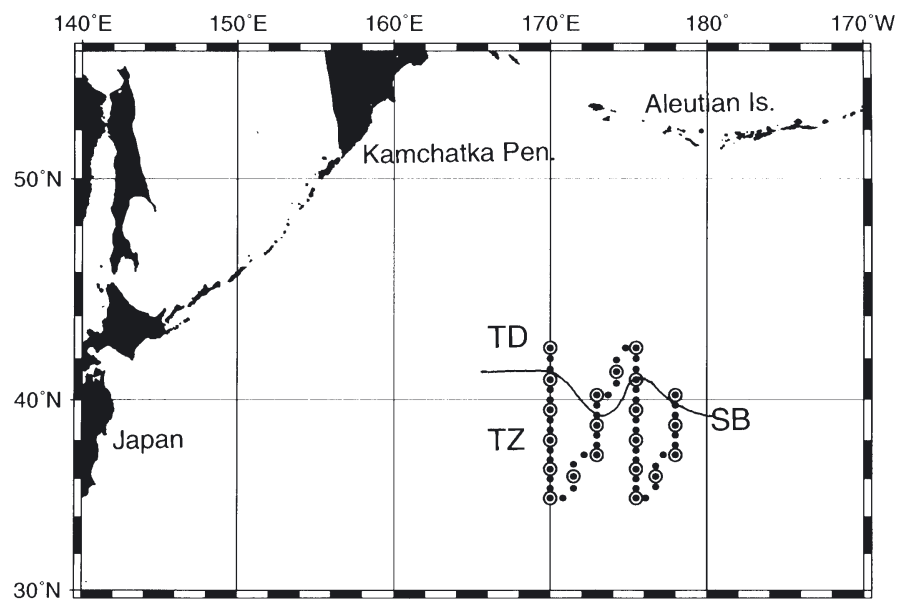

(b) July

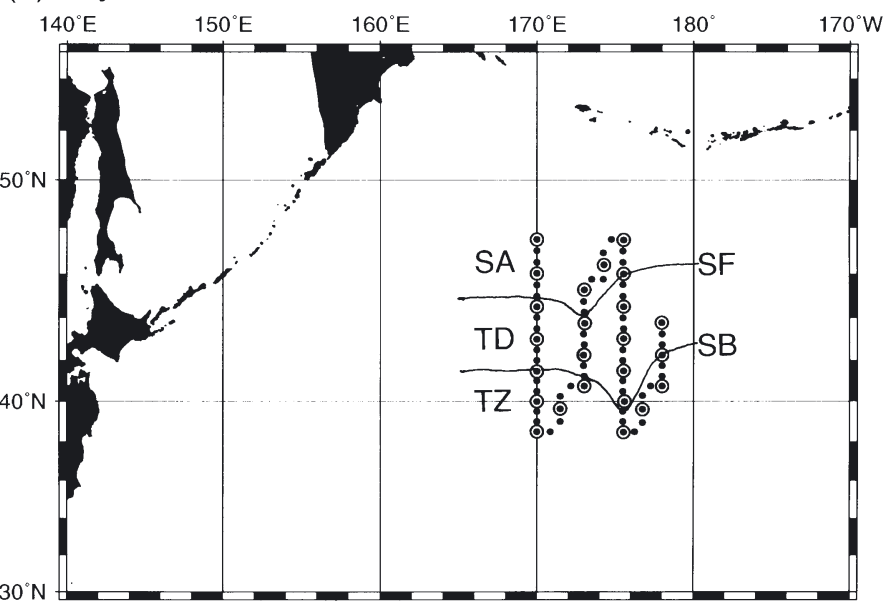

Fig. 1. Sampling localities (O) of Ommastrephes bartramii and CTD cast stations $(\bullet)$ in central North Pacific in May and July 2001. SA: subarctic domain; SB: subarctic boundary; SF: subarctic front; TD: transitional domain; TZ: transition zone

\section{MATERIALS AND METHODS}

Samples were collected in the transition zone (TZ) of the central North Pacific from May 4 to 26, 1999 and May 6 to 16, 2001, and in both the TZ and the transitional domain (TD) from July 7 to 25, 2001. The sampling localities in May and July 2001 are shown in Fig. 1. In this sampling area, the Emperor seamounts are located along ca. $170^{\circ} \mathrm{E}$. We used 2 sets of surface gillnets; one was a non-size-selective net, which comprised 30 units ( 1 unit $=7 \mathrm{~m}$ high $\times 50 \mathrm{~m}$ wide) with mesh sizes of $48,55,63,72,82,93,106,121,138$, and $157 \mathrm{~mm}$ and the other was a commercial net, which comprised 20 units with a mesh size of $115 \mathrm{~mm}$. Gillnets were deployed at dusk and retrieved at dawn on the following day. We sampled the 0 to $7 \mathrm{~m}$ layer, which corresponds to the main habitat depth of neon flying squid at night. Samples were frozen at $-30^{\circ} \mathrm{C}$ for further analysis in the laboratory. A CTD (conductivity, salinity, depth profiler) cast was made down to $500 \mathrm{~m}$ at each sampling station and between sampling stations to determine the position of the subarctic boundary and the subarctic front (Fig. 1).

Dorsal mantle length (DML), body wet weight, and wet weight of stomach contents were measured. We used the samples collected by the non-size-selective gillnet to evaluate the DML composition. Zooplankton prey were counted and identified to species or genus, depending on their state of digestion. Total body length (TL) and wet weight (WW) were measured for each taxon. All cephalopod and fish prey were identified to the lowest taxonomic level possible based on the morphology of their lower beaks and sagittal otoliths, respectively, since these prey items were highly masticated. Sagittal fish otoliths were sorted into left and right otoliths, and basically the left otoliths were counted. When the numbers of left and right otoliths differed, the larger number was taken to represent the number of fish prey. Their rostral length of the lower beak of cephalopods and the maximum diameter of sagittal fish otoliths were also measured to estimate wet weights and body sizes (DML for cephalopods and standard length [SL] for fishes), using relationships generated from intact specimens of the main prey items (Kubodera 1982, Clarke 1986, Kubodera \& Furuhashi 1987, Kubodera \& Shimazaki 1989, Smale et al. 1995, Ohizumi et al. 2001, T. Kubodera unpubl. data, H. Watanabe \& H. Ohizumi unpubl. data).

The stomach content index (SCI) was calculated as

$$
\mathrm{SCI}(\%)=\frac{\text { wet weight of stomach contents }}{\text { body wet weight }} \times 100
$$

The frequency of occurrence $(F)$ of each food item in the total number of stomachs examined, the ratio of 
each food item to the total number of food items identified $(\mathrm{Cn})$, and the ratio of the wet weight of each food item to the total wet weight of the stomach contents were calculated for Species $i$ as follows:

$F i(\%)=\frac{\text { no. of stomachs including food item } i}{\text { total no. of stomachs }} \times 100$

Cni $(\%)=\frac{\text { total no. of food item } i}{\text { total no. of food items identidied in stomachs }} \times 100$

$\mathrm{WWi}(\%)=\frac{\text { total wet weight of food item } i}{\text { total wet weight of stomach contents }} \times 100$

Using these 3 indices, an index of relative importance (IRI; Pinkas et al. 1971) of food item $i$ was calculated using the equation: IRI $i=(C n i+W W i) \times F i$
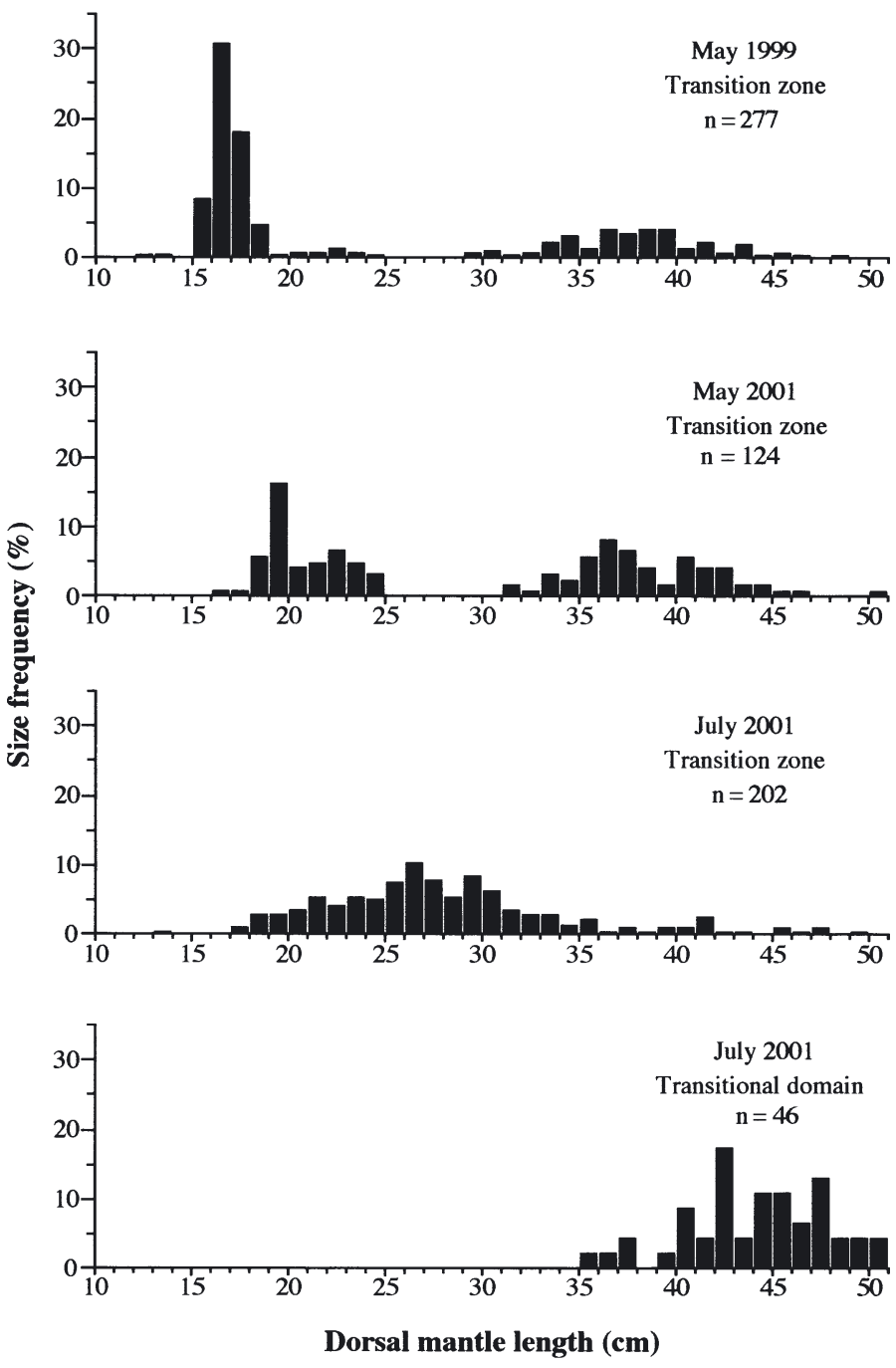

Fig. 2. Ommastrephes bartramii. Size distributions in May 1999 and 2001, and in July 2001
This index is represented by the size of a rectangle resolved by plotting the 3 values on a 3-way graph.

We were unable to estimate the body wet weight of 2 cephalopod species, Japetella diaphana and Ancistrocheirus lesueuri, and 3 micronektonic fish species, Diaphus kuroshio, Ichtyococcus elongatus, and Argyropelecus sladeni. However, because these were minor prey items with very low $C n$ and $F$ values (see Tables 1 \& 2), they did not significantly affect the wet weight composition of prey species.

\section{RESULTS}

\section{Size composition}

The frequency distribution of DML showed a clear first mode between 15 and $25 \mathrm{~cm}$ in May, representing the winter-spring cohort; this mode shifted to between 20 and $35 \mathrm{~cm}$ in July (Fig. 2), indicating a growth of 5 to $10 \mathrm{~cm}$ DML over $2 \mathrm{mo}$. Individuals that formed the first mode were distributed only in the TZ in both May and July (Fig. 2) and showed no seasonal migrations into the TD. The second mode, representing the autumn cohort, measured between 30 and $45 \mathrm{~cm}$ DML in the TZ in May, and between 35 and $50 \mathrm{~cm}$ in the TD in July, indicating a growth of 5 to $10 \mathrm{~cm}$ over 2 mo. In July, the distribution center of the larger-sized autumn cohort shifted northward into the TD, although a small part of this cohort still remained in the TZ (Fig. 2), suggesting a general northward summertime migration from the TZ to the TD.

\section{Diet composition}

We identified 32 prey species belonging to 27 genera in 397 examined stomachs (see Tables 1 \& 2). Of these stomachs, $48(12.1 \%)$ were empty. Most of the fish remains such as vertebrate and jaws found in the stomachs were identified as parts of micronektonic fishes. These fish remains did not occur in the stomachs of the winter-spring cohort in May.

\section{Winter-spring cohort (juveniles)}

The winter-spring cohort was at a juvenile stage from May to July and remained in the TZ.

May. Most prey items in the stomachs of this cohort were planktonic crustaceans, such as euphausiids and amphipods, in both 1999 and 2001 (Table 1). In 1999, euphausiids ranked first, with $C n$ and WW values of 57.1 and $51.4 \%$, respectively, followed by amphipods (Cn, 28.6\%; WW, 22.8\%). In 2001, they also mainly 
Table 1. Prey-species composition of winter-spring cohort (juveniles) of Ommastrephes bartramii in transition zone (TZ) of central North Pacific by abundance $(C n, \%)$, wet weight (WW, \%), and frequency of occurrence $(F, \%)$ in total number of stomachs examined. DML: dorsal mantle length; IRI: index of relative importance (see 'Materials and methods' for details); n: no. of stomachs examined (no. of empty stomachs); -: no data

\begin{tabular}{|c|c|c|c|c|c|c|c|c|c|c|c|c|}
\hline \multirow[t]{2}{*}{ Prey species } & \multicolumn{4}{|c|}{$\begin{array}{c}\text { May 1999: } 15.8-24.9 \mathrm{~cm} \text { DML } \\
\mathrm{n}(\mathrm{n})=4(1)\end{array}$} & \multicolumn{4}{|c|}{$\begin{array}{c}\text { May 2001: } 15.0-24.9 \mathrm{~cm} \text { DML } \\
\mathrm{n}(\mathrm{n})=50(7)\end{array}$} & \multicolumn{4}{|c|}{$\begin{array}{c}\text { July 2001: } 13.0-34.9 \mathrm{~cm} \text { DML } \\
\mathrm{n}(\mathrm{n})=136(21)\end{array}$} \\
\hline & $\mathrm{Cn}$ & WW & $F$ & IRI & $\mathrm{Cn}$ & WW & $F$ & IRI & $\mathrm{Cn}$ & WW & $F$ & IRI \\
\hline Zooplankton & 85.7 & 87.3 & 50.0 & 8651 & 100 & 100 & 42.0 & 8400 & 4.2 & 0.2 & 10.3 & 44 \\
\hline Euphausiids (unidentified) & 57.1 & 51.4 & 25.0 & 2714 & 61.7 & 22.7 & 16.0 & 1350 & 1.7 & $<0.1$ & 3.7 & 6 \\
\hline Amphipods & 28.6 & 22.8 & 25.0 & 1284 & 38.3 & 35.8 & 12.0 & 889 & 2.6 & 0.1 & 5.1 & 13 \\
\hline Phronima sedentaria & 0 & 0 & 0 & 0 & 0 & 0 & 0 & 0 & 0.3 & $<0.1$ & 0.7 & 0 \\
\hline Phronima spp. & 0 & 0 & 0 & 0 & 0 & 0 & 0 & 0 & 0.3 & $<0.1$ & 0.7 & 0 \\
\hline Unidentified & 28.6 & 22.8 & 25.0 & 1284 & 38.3 & 35.8 & 12.0 & 889 & 2.0 & 0.2 & 4.4 & 9 \\
\hline Crustaceans (unidentified) & - & 13.1 & 50.0 & - & - & 41.5 & 36.0 & - & - & $<0.1$ & 10.3 & - \\
\hline $\begin{array}{l}\text { Cephalopods } \\
\text { Gonatids }\end{array}$ & \multicolumn{11}{|c|}{ Gonatids } & 128 \\
\hline Gonatopsis borealis & 0 & 0 & 0 & 0 & 0 & 0 & 0 & 0 & 2.3 & 2.1 & 2.2 & 10 \\
\hline Gonatus spp. & 0 & 0 & 0 & 0 & 0 & 0 & 0 & 0 & 0.6 & 1.2 & 1.5 & 3 \\
\hline Berryteuthis anonychus & 0 & 0 & 0 & 0 & 0 & 0 & 0 & 0 & 0.3 & 0.1 & 0.7 & $<0.1$ \\
\hline \multicolumn{13}{|l|}{ Others } \\
\hline Onychoteuthis borealijaponica & 0 & 0 & 0 & 0 & 0 & 0 & 0 & 0 & 0.3 & 5.8 & 0.7 & 4 \\
\hline Japetella diaphana & 0 & 0 & 0 & 0 & 0 & 0 & 0 & 0 & 0.3 & - & 0.7 & - \\
\hline Abraliopsis spp. & 0 & 0 & 0 & 0 & 0 & 0 & 0 & 0 & 2.6 & 2.3 & 3.7 & 18 \\
\hline Unidentified & 14.3 & 12.7 & 25.0 & 675 & 0 & 0 & 0 & 0 & 1.3 & - & 1.5 & - \\
\hline Fishes & 0 & 0 & 0 & 0 & 0 & 0 & 0 & 0 & 87.8 & 87.9 & 29.4 & 5166 \\
\hline \multicolumn{13}{|l|}{ Myctophids } \\
\hline Ceratoscopelus warmingi & 0 & 0 & 0 & 0 & 0 & 0 & 0 & 0 & 1.7 & 3.0 & 1.5 & 7 \\
\hline Symbolophorus californiensis & 0 & 0 & 0 & 0 & 0 & 0 & 0 & 0 & 0.3 & 1.0 & 0.7 & 1 \\
\hline Electrona risso & 0 & 0 & 0 & 0 & 0 & 0 & 0 & 0 & 0.3 & 0.8 & 1.5 & 2 \\
\hline Unidentified & 0 & 0 & 0 & 0 & 0 & 0 & 0 & 0 & 0.3 & - & 1.5 & - \\
\hline \multicolumn{13}{|l|}{ Others } \\
\hline Engraulis japonicus & 0 & 0 & 0 & 0 & 0 & 0 & 0 & 0 & 1.0 & 1.2 & 2.2 & 5 \\
\hline Maurolicus imperatorius & 0 & 0 & 0 & 0 & 0 & 0 & 0 & 0 & 75.6 & 81.9 & 16.9 & 2663 \\
\hline Ichthyococcus elongatus & 0 & 0 & 0 & 0 & 0 & 0 & 0 & 0 & 0.3 & - & 0.7 & - \\
\hline Unidentified & 0 & 0 & 0 & 0 & 0 & 0 & 0 & 0 & 8.3 & - & 14.7 & - \\
\hline
\end{tabular}

fed on euphausiids and amphipods, with euphausiids showing higher $C n(61.7$ vs $38.3 \%)$ and $F(16.0$ vs $12.0 \%$ ) values, while amphipods had higher WW values than euphausiids (35.8 vs $22.7 \%$ ). The IRIs of euphausiids and amphipods were 2714 and 1284, respectively, in 1999 and 1350 and 889, respectively in 2001 (Table 1), indicating that juvenile squids fed primarily on euphausiids and secondarily on amphipods.

July. Fishes were the most common prey, as indicated by high $C n$ (87.8\%), WW (87.9\%), and F (29.4\%) values (Table 1). The IRI of fishes was 5166, while IRI values of other taxa were $<130$, indicating that the diet shifted from crustacean zooplankton to fishes in midsummer in the TZ. Most of the fish prey was composed of the sternoptychid Maurolicus imperatorius, which had very high $C n(75.6 \%)$, WW $(81.9 \%), F(16.9 \%)$, and IRI (2663) values (Table 1). The smallest individuals that fed on cephalopods and fishes were 18 and $21 \mathrm{~cm}$ DML, respectively, suggesting a shift in prey items from crustacean zooplankton to micronektonic fishes upon reaching a DML of around $20 \mathrm{~cm}$.

\section{Autumn cohort (adults)}

Individuals of the autumn cohort were at an adult stage in summer, and most of the population moved north and crossed the subarctic boundary during the summer feeding migration from the TZ into the TD.

Transition zone in May. The most common prey item was fishes both in 1999 and 2001, with $C n$ values of 74.7 and $64.0 \%$ and $F$ values of 63.8 and $70.7 \%$, followed by cephalopods $(C n, 15.7$ and $28.0 \%$; F, 53.2 and $31.7 \%$; Table 2). In terms of wet weight of prey (WW), however, fishes and cephalopods were equally important, since the WW of fish was 55.7 and $42.0 \%$ in 1999 and 2001, respectively, while the values for cephalopods were 44.1 and $57.9 \%$. In both 1999 and 2001, the IRIs were highest for fishes (8320 and 7492), followed by cephalopods (3181 and 2723; Table 2). The IRIs of other taxa such as euphausiids and amphipods were <40 in 1999 and <80 in 2001 (Table 2), suggesting that adult neon flying squid mainly prey on fishes and secondarily on cephalopods.

Among the fish prey, this cohort mainly fed on the transitional-water myctophid Symbolophorus cali- 
Table 2. Prey-species composition of autumn cohort (adults) of Ommastrephes bartramii in transition zone (TZ) and transitional domain (TD) of central North Pacific by abundance $(C n, \%)$, wet wt (WW, \%), and frequency of occurrence $(F, \%)$ in all stomachs examined. Further details given in Table 1

\begin{tabular}{|c|c|c|c|c|c|c|c|c|c|c|c|c|c|c|c|c|}
\hline \multirow[t]{2}{*}{ Prey species } & \multicolumn{4}{|c|}{$\begin{array}{c}\text { May 1999, TZ } \\
29.0-45.9 \mathrm{~cm} \text { DML } \\
\mathrm{n}(\mathrm{n})=47 \text { (3) }\end{array}$} & \multicolumn{4}{|c|}{$\begin{array}{c}\text { May 2001, TZ } \\
\text { 31.0-50.9 cm DML } \\
\mathrm{n}(\mathrm{n})=41 \text { (4) }\end{array}$} & \multicolumn{4}{|c|}{$\begin{array}{c}\text { July 2001, TZ } \\
35.0-49.9 \mathrm{~cm} \text { DML } \\
\text { n (n) }=49(6)\end{array}$} & \multicolumn{4}{|c|}{$\begin{array}{c}\text { July 2001, TD } \\
35.0-50.9 \mathrm{~cm} \text { DML } \\
\mathrm{n}(\mathrm{n})=70(6)\end{array}$} \\
\hline & $\mathrm{Cn}$ & WW & $F$ & IRI & $\mathrm{Cn}$ & WW & $F$ & IRI & $\mathrm{Cn}$ & WW & $F$ & IRI & $\mathrm{Cn}$ & WW & $F$ & IRI \\
\hline Zooplankton & 18.6 & 0.2 & 10.6 & 200 & 16.0 & 0.1 & 14.6 & 236 & 0.4 & 0.1 & 12.2 & 6 & 0 & $<0.1$ & 14.3 & 1 \\
\hline Euphausiids & 8.9 & $<0.1$ & 4.3 & 38 & 8.0 & $<0.1$ & 9.8 & 79 & 0 & 0 & 0 & 0 & 0 & 0 & 0 & 0 \\
\hline Euphausia spp. & 0.4 & $<0.1$ & 2.1 & 1 & 0 & 0 & 0 & 0 & 0 & 0 & 0 & 0 & 0 & 0 & 0 & 0 \\
\hline Crustaceans (unidentified) & - & $<0.1$ & 8.5 & - & - & $<0.1$ & 9.8 & - & - & $<0.1$ & 12.2 & - & - & $<0.1$ & 14.3 & \\
\hline Pteropods (unidentified) & 0 & 0 & 0 & 0 & - & $<0.1$ & 2.4 & - & 0 & 0 & 0 & 0 & 0 & 0 & 0 & 0 \\
\hline Cephalopods & 15.7 & 44.1 & 53.2 & 3181 & 28.0 & 57.9 & 31.7 & 2723 & 6.8 & 32.2 & 16.3 & 636 & 37.8 & 64.7 & 44.3 & 4542 \\
\hline \multicolumn{17}{|c|}{ (2) } \\
\hline Gonatus berryi & 4.2 & 9.7 & 10.6 & 148 & 0 & 0 & 0 & 0 & 0.4 & 0.9 & 2.0 & 3 & 0 & 0 & 0 & 0 \\
\hline Gonatus onyx & 2.0 & 5.1 & 6.4 & 45 & 0 & 0 & 0 & 0 & 0 & 0 & 0 & 0 & 1.3 & 4.0 & 4.3 & 23 \\
\hline Gonatopsis borealis & 0.8 & 2.1 & 2.1 & 6 & 0.5 & 1.5 & 2.4 & 5 & 0.9 & 0.5 & 4.1 & 6 & 0.4 & 0.7 & 1.4 & 2 \\
\hline \multicolumn{17}{|l|}{ Others } \\
\hline Onychoteuthis borealijaponica & 2.7 & 6.2 & 8.5 & 76 & 2.5 & 12.8 & 7.3 & 112 & 0.9 & 1.1 & 4.1 & 8 & 9.0 & 29.1 & 17.1 & 654 \\
\hline Histioteuthis inermis & 0.4 & 6.5 & 2.1 & 15 & 0 & 0 & 0 & 0 & 0 & 0 & 0 & 0 & 0 & 0 & 0 & 0 \\
\hline Histioteuthis dofleini & 0 & 0 & 0 & 0 & 0 & 0 & 0 & 0 & 0.4 & 12.5 & 2.0 & 26 & 0 & 0 & 0 & 0 \\
\hline Ommastrephes bartramii & 0.4 & 7.2 & 2.1 & 16 & 0 & 0 & 0 & 0 & 0.4 & 3.8 & 2.0 & 9 & 0 & 0 & 0 & 0 \\
\hline Galiteuthis phyllura & 0.4 & 1.4 & 2.1 & 4 & 0 & 0 & 0 & 0 & 0 & 0 & 0 & 0 & 0 & 0 & 0 & 0 \\
\hline Taonius pavo & 0 & 0 & 0 & 0 & 0.5 & 0.1 & 2.4 & 1 & 0.4 & 0.5 & 2.0 & 2 & 1.3 & 4.1 & 5.7 & 31 \\
\hline Chiroteuthis imperator & 0 & 0 & 0 & 0 & 0.5 & - & 2.4 & - & 0.4 & 5.8 & 2.0 & 13 & 0 & 0 & 0 & 0 \\
\hline Japetella diaphana & 0.8 & - & 4.3 & - & 0 & 0 & 0 & 0 & 0 & 0 & 0 & 0 & 0 & 0 & 0 & 0 \\
\hline Ancistrocheirus lesueuri & 0.8 & - & 2.1 & - & 0 & 0 & 0 & 0 & 0 & 0 & 0 & 0 & 0 & 0 & 0 & 0 \\
\hline Abraliopsis spp. & 0.4 & 1.6 & 2.1 & 4 & 0 & 0 & 0 & 0 & 0.9 & 0.4 & 4.1 & 5 & 18.9 & 16.2 & 14.3 & 501 \\
\hline Unidentified & 2.0 & - & 10.6 & - & 0 & 0 & 0 & 0 & 1.3 & - & 2.0 & - & 1.3 & - & 2.9 & - \\
\hline \multicolumn{17}{|c|}{ 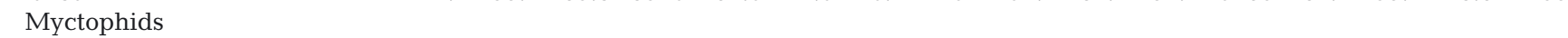 } \\
\hline Notoscopelus japonicus & 0 & 0 & 0 & 0 & 0 & 0 & 0 & 0 & 1.3 & 6.3 & 2.0 & 15 & 0 & 0 & 0 & 0 \\
\hline Diaphus theta & 0 & 0 & 0 & 0 & 0.5 & 0.8 & 2.4 & 3 & 0 & 0 & 0 & 0 & 2.6 & 4.2 & 5.7 & 39 \\
\hline Diaphus gigas & 0 & 0 & 0 & 0 & 0 & 0 & 0 & 0 & 0.4 & 2.3 & 2.0 & 6 & 0 & 0 & 0 & 0 \\
\hline Diaphus kuroshio & 0 & 0 & 0 & 0 & 3.5 & - & 7.3 & - & 0.9 & - & 4.1 & - & 0 & 0 & 0 & 0 \\
\hline Myctophum asperum & 0 & 0 & 0 & 0 & 0.5 & 0.6 & 2.4 & 3 & 0 & 0 & 0 & 0 & 0 & 0 & 0 & 0 \\
\hline Unidentified & 0 & 0 & 0 & 0 & 2.0 & - & 7.3 & - & 0.4 & - & 2.0 & - & 8.6 & - & 7.1 & - \\
\hline \multicolumn{17}{|l|}{ Others } \\
\hline Engraulis japonicus & 1.2 & 0.8 & 2.1 & 4 & 0 & 0 & 0 & 0 & 8.1 & 6.7 & 6.1 & 91 & 0 & 0 & 0 & 0 \\
\hline Bathylagus ochotensis & 0 & 0 & 0 & 0 & 1.0 & 6.5 & 2.4 & 18 & 0 & 0 & 0 & 0 & 5.6 & 9.9 & 7.1 & 111 \\
\hline Maurolicus imperatorius & 0 & 0 & 0 & 0 & 0.5 & 0.4 & 2.4 & 2 & 71.1 & 49.5 & 20.4 & 2460 & 0 & 0 & 0 & 0 \\
\hline Ichthyococcus elongatus & 2.3 & - & 6.4 & - & 1.5 & - & 7.3 & - & 0 & 0 & 0 & 0 & 0 & 0 & 0 & 0 \\
\hline Argyropelecus sladeni & 0.4 & - & 2.1 & - & 0 & 0 & 0 & 0 & 0 & 0 & 0 & 0 & 0 & 0 & 0 & 0 \\
\hline Argyropelecus spp. & 0.8 & - & 2.1 & - & 0 & 0 & 0 & 0 & 0.4 & - & 2.0 & - & 0 & 0 & 0 & 0 \\
\hline Gempylidae & 0.4 & - & 2.1 & - & 0 & 0 & 0 & 0 & 0 & 0 & 0 & 0 & 0 & 0 & 0 & 0 \\
\hline Carangidae & 0.4 & - & 2.1 & - & 0 & 0 & 0 & 0 & 0 & 0 & 0 & 0 & 0 & 0 & 0 & 0 \\
\hline Paralepididae & 0.4 & - & 2.1 & - & 4.5 & - & 9.8 & - & 0.4 & - & 2.0 & - & 0.9 & - & 2.9 & - \\
\hline Bathylagidae & 0 & 0 & 0 & 0 & 1.0 & - & 4.9 & - & 0 & - & 0 & - & 0.4 & - & 1.4 & - \\
\hline Scopelarchidae & 0 & 0 & 0 & 0 & 0.5 & - & 2.4 & - & 0 & 0 & 0 & 0 & 0 & 0 & 0 & 0 \\
\hline Unidentified & 24.3 & - & 27.7 & - & 23.0 & - & 41.5 & - & 7.2 & - & 57.1 & - & 30.4 & - & 40.0 & - \\
\hline
\end{tabular}


forniensis and subtropical water myctophids such as Ceratoscopelus warmingi. In 1999, S. californiensis was the most common species in the stomachs, with $C n$, WW, and $F$ values of $19.9,32.2$ and $23.4 \%$, respectively, followed by C. warmingi $(12.5,16.1$ and $21.3 \%$; Table 2). The IRI values of $S$. californiensis and $C$. warmingi were 1219 and 609, while the IRIs of other fish species were $<45$. In 2001, the subtropical water myctophid Electrona risso was the most common fish prey, with $C n, \mathrm{WW}$, and $F$ values of $11.0,14.3$ and $22.0 \%$, followed by $S$. californiensis $(8.5,9.9$ and $14.6 \%$ ) and C. warmingi $(6.0,9.5$ and $9.8 \%$; Table 2). The IRI of E. risso (556) was also the highest, followed by $S$. californiensis (269) and C. Warmingi (152), while values of other fish species were $<20$.

Among the cephalopod prey, the subarctic gonatids such as Gonatus berryi and Berryteuthis anonychus and the transitional-water species Onychoteuthis borealijaponica were commonly found in the stomachs of adult squid. In 1999, G. berryi was the most common cephalopod, with $C n$ and $F$ values of 4.2 and $10.6 \%$, respectively, followed by $O$. borealijaponica (2.7 and $8.5 \%$ ) and G. onyx (2.0 and 6.4\%; Table 2). In terms of WW, these species were also the most common cephalopods (5.1 to $9.7 \%$ ). The IRIs of $G$. berryi, $O$. borealijaponica, and G. onyx were as low as 148, 76, and 45 , respectively, while those of other cephalopod species were <25 (Table 2). In 2001, B. anonychus was the most common cephalopod by $C n(12.0 \%)$, WW $(23.3 \%)$, and $F(22.0 \%)$ values, followed by Gonatus spp., or G. middendorffi or O. borealijaponica (Table 2). The IRIs of these species (112 to 776) were significantly higher than those of other cephalopod species $(<20)$.

Transition zone in July. A small part of the adult population remained in the TZ in July. These individuals exclusively fed on fishes, with $C n$, WW, and $F$ values of 92.7, 67.7, and 57.1\%, respectively (Table 2). Of these fishes, Maurolicus imperatorius was the most common, with very high $C n(71.1 \%)$, WW $(49.5 \%), F(20.4 \%)$, and IRI (2460) values (as also observed in the spatiotemporally coexisting juveniles), i.e. the main fish and cephalopod prey in May (e.g. Symbolophorus californiensis and Onychoteuthis borealijaponica) disappeared from the TZ in July due to their northward migrations, and were replaced by $M$. imperatorius.

Transitional domain in July. In terms of $\mathrm{Cn}$, fishes were the most common prey $(62.2 \%)$, followed by cephalopods $(37.8 \%$; Table 2). In terms of weight (WW), however, cephalopods were more important than fishes ( 64.7 vs $35.2 \%$ ), while the $F$ values of fishes and cephalopods were similar (48.6 vs $44.3 \%$ ). As a result, the IRI values were not very different between fishes (4735) and cephalopods (4542), indicating that fishes contribute mostly to prey composition in numbers, and cephalopods in weight (Table 2).
The transitional-water species Symbolophorus californiensis and Onychoteuthis borealijaponica were 2 of the most common prey items, as observed in the TZ in May. Among the fish prey, S. californiensis was the most common, with $C n, \mathrm{WW}$, and $F$ values of 8.6, 15.9, and $12.9 \%$, respectively, followed by the subarctic bathylagid Bathylagus ochotensis (5.6, 9.9 and 7.1\%; Table 2). The IRIs of $S$. californiensis and B. ochotensis were 315 and 111, respectively, while those of other fish species were $<40$.

Among the cephalopod prey, Onychoteuthis borealijaponica was the most common in terms of both WW and $F$ (29.1 and $17.1 \%$, respectively), followed by Abraliopsis spp. (16.2 and 14.3\%; Table 2). Abraliopsis spp. were more abundant than $O$. borealijaponica ( $C n=18.9$ vs $9.0 \%$ ), but the IRI values did not differ much between these 2 categories (501 vs 654). This indicates that Abraliopsis spp. contributed mostly to prey composition in numbers and $O$. borealijaponica in weight. The IRIs for other cephalopods were all $<40$.

\section{Prey size}

Winter-spring cohort (juveniles)

Euphausiids, the main prey of squids in May, ranged from 1.3 to $1.5 \mathrm{~cm}$ TL $(\mathrm{n}=3)$. In July, the most common fish prey, Maurolicus imperatorius, was estimated to be 2.0 to $5.2 \mathrm{~cm} \mathrm{SL}($ mean $\pm \mathrm{SD}=3.8 \pm 1.4)$; this was generally smaller than other fish prey, such as Ceratoscopelus warmingi, Engraulis japonicus and Symbolophorus californiensis (4.8 to $7.7 \mathrm{~cm} \mathrm{SL;} \mathrm{Table} \mathrm{3).}$ Sizes of cephalopod prey in July ranged from 1.4 to $7.0(4.4 \pm 2.6) \mathrm{cm} \mathrm{DML}$, similar to the size range of the fish prey.

\section{Autumn cohort (adults)}

Among the common fish prey in the TZ in May, Symbolophorus californiensis, Ceratoscopelus warmingi and Electrona risso ranged in size from 9.2 to $10.2 \mathrm{~cm}$ $(9.8 \pm 0.7), 6.0$ to $8.8 \mathrm{~cm}(7.6 \pm 1.1)$, and 6.0 to $11.4 \mathrm{~cm}$ $(8.6 \pm 1.7)$ standard length, respectively, indicating that adult squid fed mainly on myctophids of 6 to $11 \mathrm{~cm} \mathrm{SL}$ (Table 3). In the TZ in July, Maurolicus imperatorius found in squid stomachs were 2.0 to $5.2 \mathrm{~cm} \mathrm{SL}$ $(3.9 \pm 1.0)$; i.e. of similar size to those consumed by spatio-temporally coexisting juveniles (Mann-Whitney $U$-test, $\mathrm{p}>0.05$ ). This indicates that in the $\mathrm{TZ}$, the preysize spectrum of adult squid shifts to a smaller range from May to July in accordance with the northward migration of the prey species into the TD (see 'Discussion'). In the TD in July, the size ranges of $S$. cali- 


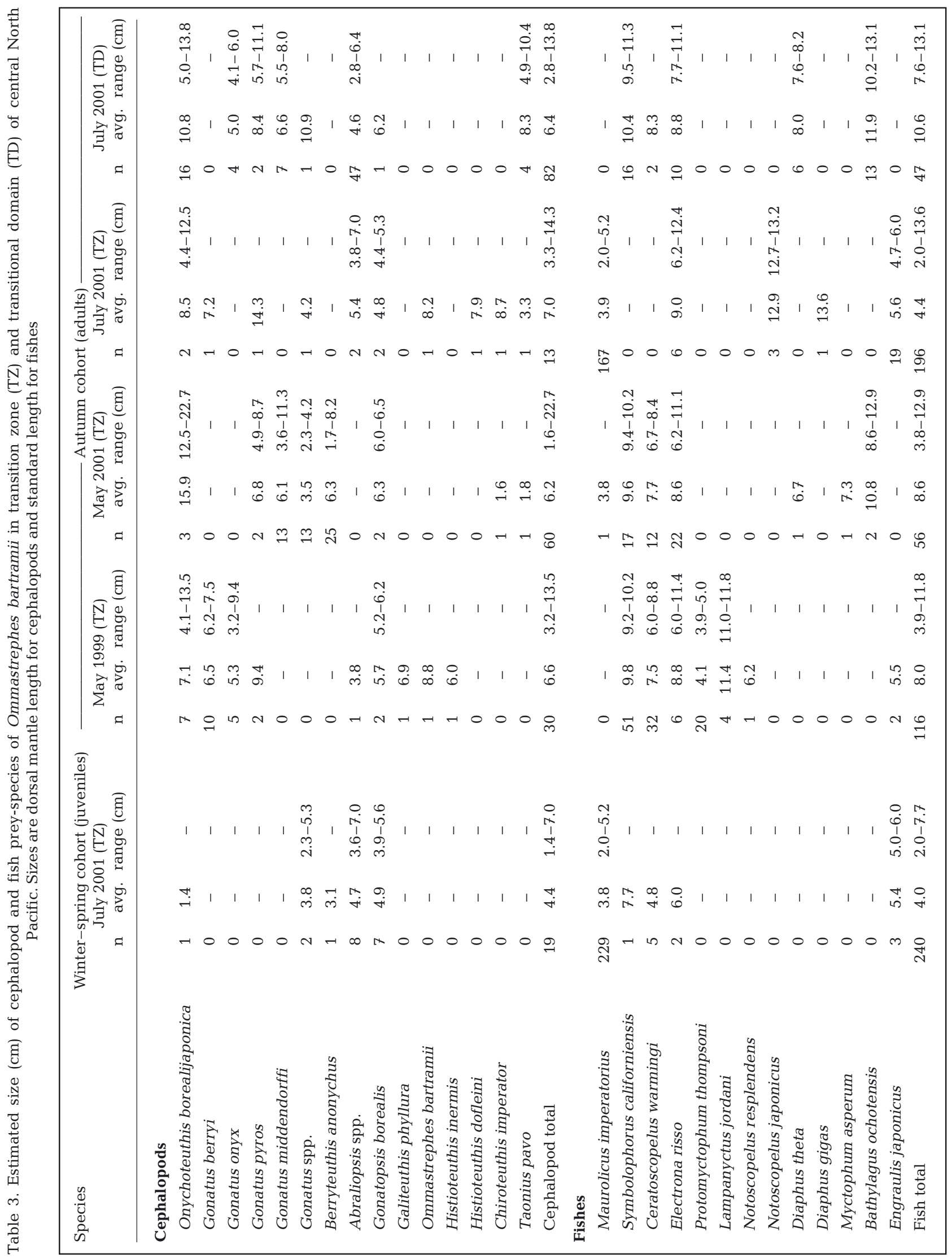


forniensis and Bathylagus ochotensis were 9.5 to $11.3 \mathrm{~cm}$ SL (10.4 \pm 0.8$)$ and 10.2 to $13.1 \mathrm{~cm} \mathrm{SL} \mathrm{(11.9 \pm}$ 1.1), respectively (Table 3 ).

Among the main cephalopod prey in the TZ in May, the size range of Onychoteuthis borealijaponica was 4.1 to $13.5 \mathrm{~cm}$ DML $(7.1 \pm 2.8)$ in 1999 and 12.5 to 22.7 $(15.9 \pm 5.4)$ in 2001 (Table 3$)$. In this month, other common cephalopod prey such as Gonatus berryi and Berryteuthis anonychus (3.2 to $9.4 \mathrm{~cm}$ DML [6.4 \pm 3.3 ] in 1999 and 1.7 to 11.3 [5.5 \pm 4.1 ] in 2001) were generally smaller than $O$. borealijaponica. In the TD in July, the estimated size range of $O$. borealijaponica was 5.0 to $13.8 \mathrm{~cm}$ DML $(10.8 \pm 2.6)$. The second most common cephalopod, Abraliopsis spp., was estimated to be 2.8 to $6.4 \mathrm{~cm}$ DML $(4.6 \pm 1.5)$.

\section{Seasonal changes in average SCI of the 2 cohorts}

In the TZ in May, the mean SCI of juveniles $(0.13 \pm$ $0.14 \%$ in 1999 and $0.18 \pm 0.22 \%$ in 2001) was significantly smaller than that of adults in both 1999 and 2001 $(0.55 \pm 0.83 \%$ in 1999 and $0.67 \pm 1.11 \%$ in 2001 ; MannWhitney $U$-test, p < 0.05). In July, however, these values did not differ between the 2 cohorts due to an increase in the SCI of juveniles $(0.39 \pm 0.53$ and $0.61 \pm$ $1.16 \%$, Mann-Whitney $U$-test, p > 0.05). This suggests that the prey environment of juveniles improved in July, when they shifted their prey from zooplankton to micronekton. In the TD in July, the mean SCI of adults was $0.57 \pm 0.74 \%$, similar to that in the TZ in both May and July (ANOVA, p > 0.05).

\section{DISCUSSION}

\section{Possible biases in diet composition analysis}

Generally, ommastrephid squids are known to discard the heads of fish prey when fish exceed 50 to $60 \%$ of the DML of the squid (Froerman 1984, Kitagawa et al. 1992). In this study, the main fish prey, myctophids and Maurolicus imperatorius, were generally less than $30 \%$ of the DML of the predator, suggesting that neon flying squid is able to feed on these micronektonic animals in their entirety. Therefore, our diet analysis may not have been heavily biased by eventual rejection of fish heads by the predator.

\section{Diet shifts in TZ from May to July}

Maurolicus imperatorius, which is endemic to the insular slope and seamount waters, is one of the dominant micronektonic fish species in the TZ around the
Emperor seamounts and the Shatsky Rise area (Parin \& Kobyliansky 1996, Sassa et al. 2002). Its biomass is very large in summer, and it occurs exclusively in the areas between 30 and $40^{\circ} \mathrm{N}$ and 160 and $180^{\circ} \mathrm{E}$, which include the TZ of our study area (Boehlert et al. 1994, Sassa et al. 2002). Its abundance probably explains why adult neon flying squid mainly depended on this sternoptychid species in the TZ in July. Juvenile squid changed their prey from crustacean zooplankton to $M$. imperatorius in July. This diet shift in summer is not only due to the high abundance of $M$. imperatorius, but also to the increasing ability of growing squids to catch micronektonic prey. $M$. imperatorius was the smallest fish species found in the stomachs of neon flying squid; this means that it was also available to juveniles as a main prey. Similar size-related diet shifts from crustacean zooplankton to micronekton have been reported for other ommastrephid squids such as Illex argentinus, I. illecebrosus, Nototodarus gouldi, and Todarodes sagittatus (Vinogradov \& Noskov 1979, O'Sullivan \& Cullen 1983, Froerman 1984, Breiby \& Jobling 1985, Maurer \& Bowman 1985, Ivanovic \& Brunetti 1994, Quetglas et al. 1999). The increase in SCI of the juveniles from May to July suggests that their food environment improves in July due to their expanding prey size range and also as a result of increased $M$. imperatorius biomass in summer.

\section{Feeding habits related to northward migration}

Fig. 3 shows the predator-prey relationship between juvenile and adult neon flying squid and their main prey in relation to the northward migration of the squid. Symbolophorus californiensis and Onychoteuthis borealijaponica are so-called transitional-water species that undertake extensive northward feeding migrations from the TZ to the TD between spring and summer (Ogawa 1961, Naito et al. 1977b, Mishima 1981, Kubodera et al. 1983, Willis et al. 1988). These species were the top 2 prey items of adult squid in both the TZ in May and the TD in July. This predator-prey relationship is maintained from May to July since their seasonal migration patterns are spatio-temporally similar to each other (Fig. 3).

Gonatid squids such as Gonatus berryi, G. middendorffi and Berryteuthis anonychus are typical subarctic species and rarely occur in transitional waters (TZ and TD) in the summer (Kubodera et al. 1983, Kubodera \& Jefferts 1984, Kubodera \& Shimazaki 1989). Our results showed that adult neon flying squid frequently fed on these species in the TZ only in May, reflecting their distribution in the $\mathrm{TZ}$ in winter and spring and their northward migration to subarctic waters in summer (Fig. 3). 

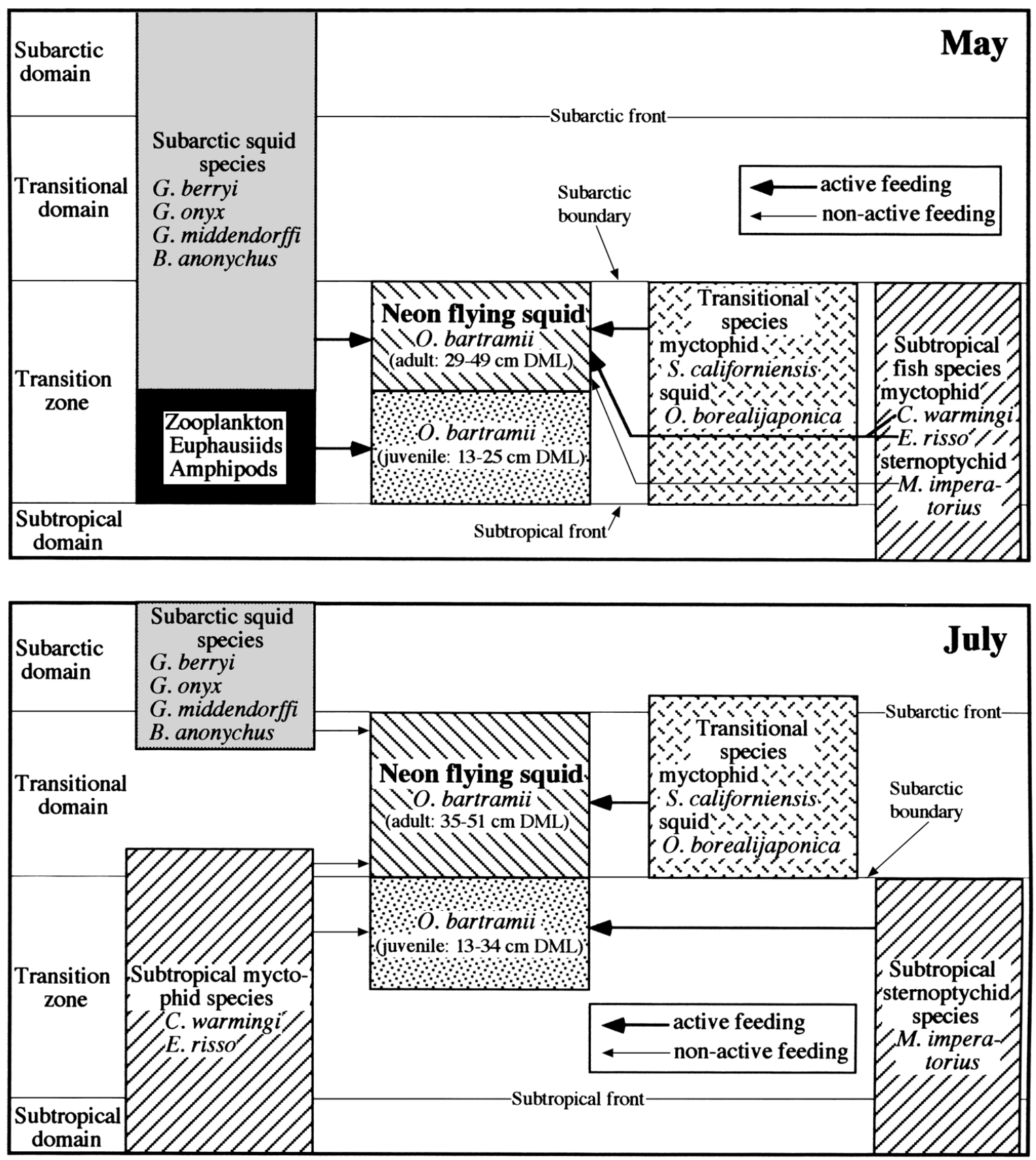

Fig. 3. Predator-prey relationship and seasonal northward migration patterns of Ommastrephes bartramii and their prey in transitional waters of central North Pacific in May and July. Full specific names of prey are given in Table 2

Although juvenile neon flying squid have been reported to undertake northward migrations into the TD in autumn (Murata \& Hayase 1993), they remained in the TZ in July during this study, and mainly fed on Maurolicus imperatorius. The biomass of $M$. imperatorius is very high (ca. $14 \mathrm{~g} \mathrm{~m}^{-2}$ ) at night in the 0 to $20 \mathrm{~m}$ layer near the Shatsky Rise area (Sassa et al. 2002), which would support the flying squid population in the TZ in summer.
Feeding habits related to diel vertical migration patterns

Diel vertical migration patterns of adult neon flying squid and their prey, as well as possible predator-prey relationships estimated from stomach-content analyses are shown in Fig. 4. Adult neon flying squid larger than ca. $30 \mathrm{~cm}$ DML (mostly the autumn cohort in this study) are mainly distributed in the 300 to $600 \mathrm{~m}$ layer during 


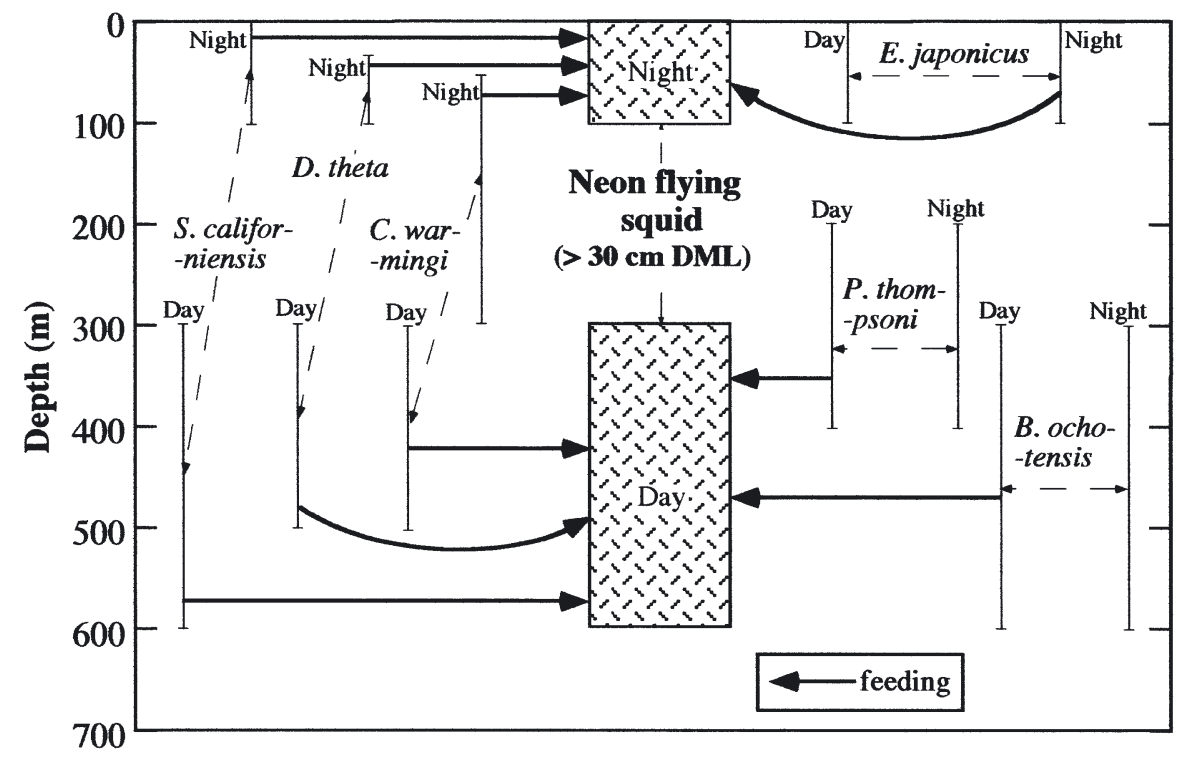

Fig. 4. Predator-prey relationship and diel vertical migration patterns of adult Ommastrephes bartramii $>30 \mathrm{~cm}$ in dorsal mantle length (DML) and fish prey in transitional waters of central North Pacific. Full specific names of prey are given in Table 2

the daytime and migrate to the 0 to $100 \mathrm{~m}$ layer at night in transitional waters of the central North Pacific (Nakamura 1991, 1993, Tanaka 2001). Among the fish prey of the adults, Protomyctophum thompsoni and Bathylagus ochotensis are non-migratory, and throughout the day are mainly distributed in the 200 to $400 \mathrm{~m}$ layer and the 300 to $600 \mathrm{~m}$ layer, respectively (Miya 1995, Watanabe et al. 1999). The distribution depth of these fishes overlaps with that of adult squid only during the daytime in the upper mesopelagic zone (Fig. 4). In contrast, Japanese anchovy Engraulis japonicus is mainly distributed in the epipelagic zone shallower than $100 \mathrm{~m}$ during both day and night, and is expected to be available to adult squid only at night (Fig. 4). Adult neon flying squid fed on all these nonmigratory fishes, suggesting they feed both during the day in the mesopelagic zone and at night in the epipelagic. It is possible that they feed on migratory myctophids such as Symbolophorus californiensis and Ceratoscopelus warmingi during both day and night, since their diel vertical migration patterns overlap each another (Fig. 4). Since $S$. californiensis and $C$. warmingi are abundant in the transitional waters of the western and central North Pacific (Wisner 1976, Willis et al. 1988, Watanabe et al. 1999), their $24 \mathrm{~h}$ availability would be beneficial to adult neon flying squid.

In contrast to adults, early juveniles of $<20 \mathrm{~cm}$ DML have been observed in the upper $10 \mathrm{~m}$ during both day and night (Murata 1988, H. Watanabe unpubl. data). This may indicate that they occur in the zooplankton- rich epipelagic zone throughout the whole $24 \mathrm{~h}$. This distribution pattern would be favorable for early juveniles (which were found mainly in May in the TZ), since they exclusively feed on crustacean zooplankton. These juveniles are thought to begin active diel vertical migrations upon reaching 20 to $30 \mathrm{~cm} \mathrm{DML}$, corresponding to the size at which their feeding habits switch from crustacean zooplankton to micronekton.

\section{Predation impact of adult neon flying squid on myctophids}

Results of CTD casts together with data on the diel vertical migration pattern of adult squids indicate that their day and night habitat-temperatures ranged from 5 to $8^{\circ} \mathrm{C}$ at depths of 300 to $600 \mathrm{~m}$ in the day and 10 to $16^{\circ} \mathrm{C}$ at depths of 0 to $100 \mathrm{~m}$ in the night in the TD in July (Tanaka 2001, T. Ichii unpubl. data). For another ommastrephid species, Illex illecebrosus, of $>20 \mathrm{~cm} \mathrm{DML}$, daily rations were estimated to be $5.2 \%$ of body wet weight at $7^{\circ} \mathrm{C}$ and $6.7 \%$ at $16^{\circ} \mathrm{C}\left(\mathrm{O}^{\prime}\right.$ Dor et al. 1980). Since 7 and $16^{\circ} \mathrm{C}$ are similar to the habitattemperature ranges of adult neon flying squid during the daytime and nighttime, respectively, and the feeding habits of $I$. illecebrosus of $>20 \mathrm{~cm}$ DML are also similar to those of adult neon flying squid (Froerman 1984, Maurer \& Bowman 1985), we adopted these daily rations to represent those of adult neon flying squid. Hence, we adopted a daily ration of $6.0 \%$ of body wet weight (i.e. the average of $5.2 \%$ for the day and $6.7 \%$ for the night). The biomass of adult neon flying squids is estimated to have been 240 to $610 \mathrm{mg}$ wet weight $\mathrm{m}^{-2}$ in the study area in July over the past $10 \mathrm{yr}$ (Ichii 2002, and unpubl. data). Furthermore, myctophids, most of which were composed of Symbolophorus californiensis, accounted for $25.3 \%$ of the total stomach contents (WW) of adult squid in in the TD in July (Table 2). Based on these data and the estimated daily ration, an adult neon flying squid is believed to consume 3.6 to $9.3 \mathrm{mg}$ wet weight myctophids $\mathrm{m}^{-2}$ every day. The biomass of vertical migratory trans-Pacific myctophid fishes (mainly $S$. californiensis) is estimated to be $5.2 \mathrm{~g}$ wet weight $\mathrm{m}^{-2}$ in the Oyashio-Kuroshio transitional waters of the western North Pacific in summer (H. Watanabe unpubl. data). Since their abundance in this region and the TD in the central North Pacific (Sassa et al. 2002) is similar, we adopted this value for the biomass of vertical migratory myctophids 
in the TD of the study area. According to Murata \& Hayase (1993), adult neon flying squid are mainly distributed in the TD for ca. $70 \mathrm{~d}$, from early July to midSeptember. Therefore, the amount of myctophid prey consumed by adult squid during the summer $(70 \mathrm{~d})$ is estimated as 273.2 to $694.5 \mathrm{mg}$ wet weight $\mathrm{m}^{-2}$, which is equivalent to 4.9 to $12.4 \%$ of the total estimated biomass of vertically migrating myctophids. These estimates are probably conservative, because myctophids that we could not identify to species (and hence for which we could not estimate body wet weight) due to digestion of sagittal otoliths accounted for $27.0 \%$ of the total number of fish prey identified in the TD in July.

Acknowledgements. We are grateful to the captains, officers, and crew of the FRV 'Kaiun-Maru' of the Aomori Prefectural Fisheries Experiment Station and the FRV 'Wakatori-Maru' of Sakai Fisheries Senior High School in Tottori Prefecture for their assistance in field sampling. We also thank Emeritus Professor K. Kawaguchi of the Ocean Research Institute, University of Tokyo, and Mr. N. Baba and Dr. M. Sakai of the Japanese Fisheries Agency (JFA) for their helpful suggestions and criticisms of the manuscript. Dr. A. Yatsu and Dr. K. Nagasawa of the JFA, Dr. T. Wakabayashi of the Tokyo Business Service Company, and Dr. K. Phillips of the University of Tasmania made helpful comments. This research was supported by a grant from the JFA.

\section{LITERATURE CITED}

Arimoto Y, Kawamura A (1998) Characteristics of the fish prey of neon flying squid, Ommastrephes bartramii, in the central North Pacific. Report of the 1996 annual meeting on resources and fisheries on squids, National Research Institute of Far Seas Fisheries, Shizuoka (in Japanese)

Boehlert GW, Wilson CD, Mizuno K (1994) Populations of the sternoptychid fish Maurolicus muelleri on seamounts in the central North Pacific. Pac Sci 48:57-69

Breiby A, Jobling M (1985) Predatory role of the flying squid (Todarodes sagittatus) in north Norwegian waters. Northwest Atl Fish Organ Sci Coun Stud 9:125-132

Clarke MR (1986) A handbook for the identification of cephalopod beaks. Clarendon Press, Oxford

Favorite F, Dodimead AJ, Nasu K (1976) Oceanography of the subarctic Pacific region, 1960-71. Bull Int Natl N Pac Fish Comm 33:1-187

Filippova YA (1974) Feeding habits of oceanic squid of the family Ommastrephidae. Tr Vses Nauchno-Issled Inst Norsk Rybn Khoz Okeanogr 99:123-132

Froerman YM (1984) Feeding spectrum and trophic relationships of short-finned squid (Illex illecebrosus) in the northwest Atlantic. Northwest Atl Fish Organ Sci Coun Stud 7: $67-75$

Ichii T (2002) Resource and fishery ground. In: Nasu K, Okutani T, Ogura M (eds) The squids. Seizando Press, Tokyo, p 195-209 (in Japanese)

Ivanovic ML, Brunetti NE (1994) Food and feeding of Illex argentinus. Antarct Sci 6:185-193

Kitagawa D, Ishito Y, Okuyama Y, Sakurai Y, Inada T (1992) Preys discarded by the Japanese common squid, Todarodes pacificus, occurring in the stomachs of brown hakeling, Physiculus maximowiczi. Bull Tohoku Natl Fish Res Inst 54:59-66 (in Japanese with English abstract)
Kubodera T (1982) Ecological studies of pelagic squids in the subarctic Pacific region. PhD thesis, Hokkaido University, Hakodate (in Japanese)

Kubodera T, Furuhashi M (1987) A manual for identification of myctophid fishes and squids in the stomach contents. Report on the development of ecosystem modeling in the northern North Pacific, supplement. Japanese Fisheries Agency, Tokyo (in Japanese)

Kubodera T, Jefferts K (1984) Distribution and abundance of the early life stages of squid, primarily Gonatidae (Cephalopoda, Oegopsida), in the northern North Pacific. Part 2. Bull Natl Sci Mus Ser A (Zool) 10:165-193

Kubodera T, Shimazaki K (1989) Cephalopods from the stomach contents of the pomfret (Brama japonica Hilgendorf) caught in surface gillnets in the northern North Pacific. J Cephalopod Biol 1:71-83

Kubodera T, Pearcy WG, Murakami K, Kobayashi T, Nakata J, Mishima S (1983) Distribution and abundance of squids caught in surface gillnets in the subarctic Pacific, 1977-1981. Mem Fac Fish Hokkaido Univ 30:1-49

Maurer RO, Bowman RE (1985) Food consumption of squids (Illex illecebrosus and Loligo pealei) off the Northeastern United States. Northwest Atl Fish Organ Sci Coun Stud 9: $117-124$

Mishima S (1981) On the passing over of subtropic fishes to the subarctic region in the summer season. Spec Vol Res Inst North Pac Fish Hokkaido Univ Fac Fish 61-71 (in Japanese with English abstract)

Miya M (1995) Some aspects of the biology of Bathylagus ochotensis (Pisces: Bathylagidae) in Sagami Bay, central Japan. Bull Mar Sci 56:173-184

Mori J, Kubodera T, Baba N (2001) Squid in the diet of northern fur seals, Callorhinus ursinus, caught in the western and central North Pacific Ocean. Fish Res 52:91-97

Murata M (1988) On the flying behavior of neon flying squid Ommastrephes bartramii observed in the central and north-western North Pacific. Nippon Suisan Gakkaishi 54: 1167-1174 (in Japanese with English abstract)

Murata M (1990) Oceanic resources of squids. Mar Behav Physiol 18:19-71

Murata M, Hayase S (1993) Life history and biological information on flying squid (Ommastrephes bartramii) in the North Pacific Ocean. Bull Int Natl N Pac Comm 53: $147-182$

Naito M, Murakami K, Kobayashi T (1977a) Growth and food habit of oceanic squids (Ommastrephes bartramii, Onychoteuthis borealijaponica, Berryteuthis magister and Gonatopsis borealis) in the western subarctic Pacific region. Spec Vol Res Inst North Pac Fish Hokkaido Univ Fac Fish 339-351 (in Japanese with English abstract)

Naito M, Murakami K, Kobayashi T, Nakayama N, Ogasawara J (1977b) Distribution and migration of oceanic squids (Ommastrephes bartramii, Onychoteuthis borealijaponica, Berryteuthis magister and Gonatopsis borealis) in the western subarctic Pacific region. Spec Vol Res Inst North Pac Fish Hokkaido Univ Fac Fish 321-337 (in Japanese with English abstract)

Nakamura Y (1991) Tracking of the mature female of flying squid, Ommastrephes bartramii, by an ultrasonic transmitter. Bull Hokkaido Natl Fish Res Inst 55:205-208

Nakamura Y (1993) Vertical and horizontal movements of mature females of Ommastrephes bartramii observed by ultrasonic telemetry. In: Okutani T, O'Dor RK, Kubodera T (eds) Recent advances in fisheries biology, Tokai University Press, Tokyo, p 331-336

O'Dor RK, Durward RD, Vesey E, Amaratunga T (1980) Feeding and growth in captive squid, Illex illecebrosus, and the 
influence of food availability on growth in natural populations. Int Comm Nortwest Atl Fish Sel Pap 6:15-21

Ogawa T (1961) Study on the fishes of the family Myctophidae in the northeastern sea area along the Pacific coast of Japan. Part 1. Species and distribution. Bull Tohoku Reg Fish Res Lab 19:81-89 (in Japanese with English abstract)

Ohizumi H, Watanabe H, Moku M, Kawahara S (2001) Species identification for otoliths of myctophid fishes in the western North Pacific. Aquabiology. Seibutsu Kenkyusha Press, Tokyo (in Japanese with English abstract)

Okutani T, Satake Y (1978) Squids in the diet of 38 sperm whales caught in the Pacific waters off northeastern Honshu, Japan, February 1977. Bull Tokai Reg Fish Res Lab 93:13-27

Okutani T, Satake Y, Ohsumi S, Kawakami T (1976) Squids eaten by sperm whales caught off Joban district, Japan, during January-February, 1976. Bull Tokai Reg Fish Res Lab 87:67-113

O'Sullivan D, Cullen JM (1983) Food of the squid Nototodarus gouldi in Bass Strait. Aust J Mar Freshw Res 34:261-285

Parin NV, Kobyliansky SG (1996) Diagnoses and distribution of fifteen species recognized in genus Maurolicus Cocco (Sternoptychidae, Stomiiformes) with a key to their identification. Cybium 20:185-195

Pearcy WG (1991) Biology of the transition region. NOAA Tech Rep NMFS 105:39-55

Pinkas L, Oliphant MS, Iverson ILK (1971) Food habits of albacore, bluefin tuna, and bonito in California waters. Calif Fish Game 152:1-105

Quetglas A, Alemany F, Carbonell A, Merella P, Sánchez P (1999) Diet of the European flying squid Todarodes sagittatus (Cephalopoda: Ommastrephidae) in the Balearic Sea (western Mediterranean). J Mar Biol Assoc UK 79:479-486

Roper CFE, Sweeney MJ, Nauen CE (1984) FAO species catalogue, Vol 3, Cephalopods of the world. An annotated and illustrated catalogue of species of interest to fisheries. FAO Fish Synop 125:1-277

Sassa C, Kawaguchi K, Kinoshita T, Watanabe C (2002) Assemblages of vertical migratory mesopelagic fish in the transitional region of the western North Pacific. Fish Oceanogr 11:193-204

Seki MP (1993a) The role of neon flying squid, Ommastrephes bartramii, in the North Pacific pelagic food web. Bull Int Natl N Pac Comm 53:207-215

Editorial responsibility: Otto Kinne (Editor),

Oldendorf/Luhe, Germany
Seki MP (1993b) Trophic relationships of Ommastrephes bartramii during winter migrations to subtropical waters north of the Hawaiian Islands. In: Okutani T, O'Dor RK, Kubodera T (eds) Recent advances in cephalopod fisheries biology. Tokai University Press, Tokyo, p 523-529

Shevtsov GA (1972) Feeding habits of the squid Ommastrephes bartramii Le Seur in the Kurile-Hokkaido region. Hydrobiol J 8:77-80

Smale MJ, Watson G, Hecht T (1995) Otolith atlas of southern African marine fishes. Ichthyological monographs, No. 1. JLB Smith Institute of Ichthyology, Grahamstown, South Africa

Tanaka H (2001) Tracking the neon flying squid by the biotelemetry system in the central North Pacific Ocean. Aquabiology. Seibutsu Kenkyusha Press, Tokyo (in Japanese with English abstract)

Taniguchi A (1981) Plankton productivities in the Pacific subarctic boundary zone: food conditions of the migrating pelagic fishes. Spec Vol Res Inst North Pac Fish Hokkaido Univ Fac Fish 23-35 (in Japanese with English abstract)

Tung IH (1981) On the fishery and the biology of the squid Ommastrephes bartramii (LeSueur), in the northwest Pacific Ocean. Rep Inst Fish Biol Minist Econ Aff Natl Taiwan Univ 3: 12-37

Vinogradov VI, Noskov AS (1979) Feeding of short-finned squid, Illex illecebrosus, and long-finned squid, Loligo pealei, off Nova Scotia and New England, 1974-75. Int Comm Nortwest Atl Fish Sel Pap 5:31-36

Watanabe H, Moku M, Kawaguchi K, Ishimaru K, Ohno A (1999) Diel vertical migration of myctophid fishes (family Myctophidae) in the transitional waters of the western North Pacific. Fish Oceanogr 8:115-127

Willis JM, Pearcy WG, Parin NV (1988) Zoogeography of midwater fishes in the subarctic Pacific. Bull Ocean Res Inst Univ Tokyo 26 (Part II):79-142

Wisner RL (1976) The taxonomy and distribution of lanternfishes (family Myctophidae) of the eastern Pacific Ocean. Bay St Louis, Mississippi, Navy Ocean Research and Development Activity report no. 3

Yatsu A, Tanaka H, Mori J (1998) Population structure of the neon flying squid, Ommastrephes bartramii, in the North Pacific Ocean. In: Okutani T (ed) Large pelagic squids, Japan Marine Fishery Resource Research Center, Tokyo, p 31-48

Submitted: June 16, 2003; Accepted: September 30, 2003 Proofs received from author(s): January 20, 2004 